\title{
PEMBENTUKAN KARAKTER ANAK PADA LAGU TOKECANG, JAWA BARAT
}

\author{
Shintya Putri Setiowati ${ }^{1}$ \\ Universitas Surabaya \\ Shintya0901@gmail.com
}

\begin{abstract}
Indonesian culture is very diverse with forms ranging from dance, batik cloth, folklore, folk music and songs, traditional clothing, traditional houses, traditional food and drinks, traditional games, performing arts, rituals and so on. At the writing of this library research, the researcher focused on folk songs that are famous in West Java. The title song is Tokecang. The thing related to this song is that a simple song sung by children has a deep meaning. In this literature review, researchers associate Tokecang songs with the formation of children's characters. The formation of children's characters in the Tokecang song teaches that we, as social beings, must have an attitude of affection and social care. Affection is an emotional reaction to a person, animal, or object.
\end{abstract}

Keywords: Tokecang, song, children

\section{PENDAHULAN}

Indonesia sebagai negara yang terbentang dari Sabang sampai dengan Merauke, memiliki budaya dengan berbagai macam karya seni dan etnik yang unik. Di antara karya seninya berupa seni tari, kain batik, cerita rakyat, musik dan lagu daerah, pakaian tradisional, rumah adat, makanan dan minuman tradisional, permainan tradisional, seni pertunjukan, ritual dan sebagainya. Pada karya seni lagu, tiap daerah memiliki lagu-lagu yang khas dengan daerahnya masing-masing. Lagu-lagu daerah, seperti Tokecang dari Jawa Barat, Jaranan dari Jawa Tengah, Ampar Ampar Pisang di Kalimantan Selatan, Yamko Rambe Yamko dari Papua, Butet dari Batak, dan lagu daerah lainnya memiliki makna yang sarat akan pesan moral kehidupan sehari-hari dan menunjukkan perilaku-perilaku yang positif. Namun sangat memprihatinkan bagi anak-anak Indonesia yang mulai melupakan lagu-lagu daerah. Melihat jaman yang serba canggih dengan perkembangan internet yang semakin meluas, anak-anak dapat lebih mudah mengakses lagu-lagu dari perangkat yang dimiliki seperti handphone atau laptop. Lagu yang mereka dengar pun sudah banyak dipengaruhi oleh musik barat atau lagu-lagu Indonesia bertemakan percintaan antara dua insan yang di sedang mabuk asmara, perselingkuhan, kesenangan dunia, dan lagu sejenis lainnya. Seharusnya anakanak dapat menikmati lagu sesuai dengan usianya seperti lagu-lagu daerah karena makna yang terkandung dalam setiap lirik lagu akan bisa menjadikan anak memahami dan menerapkan pesan yang terkandung didalamnya, misalnya karakter mengenal arti keagamaan, arti kerjasama, arti kepedulian, arti dari kepatuhan, kesopanan, dan kedisiplinan. Aspek nilai karakter tersebut akan ada dalam setiap makna yang terkandung dalam setiap lagu. Ditambahkan dengan artikel Pikiran Rakyat (2016), Ubun R. Kubarsah (seorang penggagas lagu anak-anak daerah langgam Sunda, Cirebon, Betawi) mengatakan "Lagu daerah ini sangat dahsyat, karena mereka bisa bernyanyi dan bergembira, dengan isi lagu yang mendidik, dan itu menjadi bagian dari pembentukan karakter". 


\section{4 | JURNAL ILMU BUDAYA}

Pada penulisan ini, penulis fokus pada lagu daerah dari Jawa Barat Tokecang. Lagu tersebut yang menceritakan seseorang yang terlalu banyak makan atau rakus. Pesan ini penting bagi anak-anak jika memahami lirik atau syair lagu ini karena melambangkan kerakusan atau keserakahan sehingga tidak memiliki kepedulian terhadap orang lain dan hanya memikirkan tentang dirinya sendiri (budayajawa.id/makna-lagu-jawa-barat-

tokecang). Ketua Paguyuban Pasundan Didi Turmudzi berharap Dinas Pendidikan Jawa Barat dapat menyerap lagu-lagu Sunda sebagai media pembentukan karakter anak. Di tengah masyarakat yang kian modern dan lemahnya fungsi keluarga, lagu Sunda bisa menjadi kekuatan untuk membentuk karakter anak. "Lagu kalau dibawakan secara benar pengaruhnya akan sangat dalam," ujarnya (www.intipesan.com). Dari uraian tersebut, rumusan pada penulisan ini "Bagaimana pembentukan karakter anakanak pada lagu daerah Tokecang?”

\section{KAJIAN TEORI}

\section{A. Pembentukan Karakter pada Anak}

Megawangi (2010) menyebutkan ada sembilan karakter yang penting untuk ditanamkan dalam pembentukan karakter anak. Berbagai karakter tersebut sejalan dengan nilai-nilai kearifan lokal yang mengandung nilai-nilai luhur universal, meliputi:

1. Cinta kepada Tuhan dan alam semesta beserta isinya

2. Tanggung jawab, kemandirian, dan kedisiplinan

3. Kejujuran

4. Hormat dan sopan santun

5. Kasih sayang, kepedulian, dan kerja sama

6. Percaya diri, kreatif, kerja keras dan pantang menyerah

7. Keadilan dan kepemimpinan
8. Baik dan rendah hati

9. Toleransi, cinta damai, dan persatuan

Pembentukan karakter merupakan bagian penting dalam dunia pendidikan saat ini. Undang-Undang Republik Indonesia No. 20 tahun 2003 tentang Sistem Pendidikan Nasional menyebutkan bahwa tujuan pendidikan nasional adalah mengembangkan kemampuan dan membentuk watak serta peradaban bangsa yang bermartabat dalam rangka mencerdaskan kehidupan bangsa.

Untuk mewujudkan tujuan tersebut pendidikan karakter seharusnya diberikan kepada anak-anak sedini mungkin. Sejalan dengan itu, Kartini (2014) berpendapat bahwa jika sejak dini anak diperkenalkan dengan lagu daerah yang berisi petuah, pendidkan moral, dan budi pekerti, maka kelak jika sudah dewasa akan berakhlak baik. Salah satu cara untuk membentuk karakter anak-anak adalah dengan cara memperkenalkan lagu-lagu yang bermuatan nilai-nilai positif. Hal ini disebabkan di dalam lagu daerah tersebut terkandung beberapa nilai pendidikan, di antaranya menanamkan nilai sosial, nilai sejarah, nilai kejujuran, sportivitas, menghargai orang lain, pembentukan fisik, dan lain sebagainya.

\section{B. Lagu Daerah}

Menurut Banoe (2011), Lagu daerah di Indonesia yakni lagu dari daerah tertentu atau wilayah budaya tertentu, lazimnya dinyatakan dalam syair atau lirik bahasa wilayah (daerah) tersebut baik lagu rakyat maupun lagu-lagu ciptaan baru. Tanah air Indonesia sangat kaya dengan lagu-lagu daerah. Hampir setiap daerah memiliki lagunya sendiri-sendiri sebagai gambaran kehidupan masyarakat setempat secara umum.

Malatu (2014) mengatakan bahwa lagu daerah adalah lagu yang berasal dari suatu daerah menjadi populer dan banyak dinyanyikan oleh rakyat daerah tersebut maupun rakyat lainnya. Lagu daerah 


\section{5 | JURNAL ILMU BUDAYA}

Indonesia tidak hanya sekedar alunan musik yang enak untuk didengar, tetapi juga memiliki fungsi, antara lain untuk upacara adat, pengiring pertunjukan, pengiring permainan tradisional, dan media komunikasi.

Seperti yang dikatakan Setyobudi, dkk (2007), walaupun ada lagu-lagu khusus yang aturannya tetap dan bersifat magis untuk ritual adat dan keagamaan, kebanyakan lagu-lagu daerah dipakai sebagai sarana hiburan masyarakat dan dekat dengan rakyat jelata. Akibatnya, lagu-lagu daerah juga sering disebut lagu rakyat. Lagu daerah memiliki ciri serta karakter tersendiri. Bahasa dan gaya yang digunakan sesuai dengan bahasa dan gaya daerah setempat. Lagu daerah biasanya merujuk kepada sebuah lagu yang mempunyai irama khusus bagi sebuah daerah.

Ali (2010) menjelaskan beberapa ciri khas lagu daerah, antara lain sebagai berikut:

1. Menceritakan tentang keadaan lingkungan ataupun budaya masyarakat setempat yang sangat dipengaruhi oleh adat istiadat setempat.

2. Bersifat sederhana sehingga untuk mempelajari lagu daerah tidak membutuhkan pengetahuan musik yang cukup mendalam seperti membaca dan menulis not balok.

3. Jarang diketahui pengarangnya.

4. Mengandung nilai-nilai kehidupan, unsur-unsur kebersamaan sosial, serta keserasian dengan lingkungan hidup sekitar.

5. Sulit dinyanyikan oleh seseorang yang berasal dari daerah lain, karena kurangnya penguasaan dialek atau bahasa setempat sehingga penghayatannya kurang maksimal.

6. Mengandung nilai-nilai kehidupan yang unik dan khas.

Dapat disimpulkan bahwa lagu daerah adalah lagu yang berasal dari daerah tertentu dengan ide penciptaan berdasarkan atas budaya dan adat istiadat suatu daerah tertentu. Didalam lagu tersebut terkandung suatu makna, pesan untuk masyarakat serta suasana/keadaan masyarakat setempat, dan bahasa yang digunakan adalah bahasa daerah setempat.

1) Lagu Daerah Tokecang,

Pada website budayaindonesia.org/Tokecang-2, lagu Tokecang yang merupakan lagu daerah Jawa Barat ini adalah lagu yang cukup populer tidak hanya di kalangan masyarakat sunda namun juga di luar lingkup masyarakat Sunda. Lagu Sunda terkenal ini sudah beberapa kali diaransemen dengan musik pop agar lebih mudah diterima di masyarakat. Lagu Sunda Tokecang termasuk lagu tradisional Indonesia paling terkenal karena sering dinyanyikan dan digunakan sebagai lagu pengiring permainan tradisional dan sempat dijadikan soundtrack sinetron anak-anak. Lagu daerah Tokecang adalah lagu tradisional anak-anak yang sudah menasional mulai dari anak-anak hingga orang dewasa mengenal lagu ini karena diajarkan pula di berbagai sekolah. Lagu daerah Sunda ini disukai karena berirama riang, bertempo cepat, dengan lirik lagu yang jenaka.

\section{HASIL DAN PEMBAHASAN}

Lagu daerah adalah lagu yang berasal dari daerah tertentu dengan ide penciptaan berdasarkan atas budaya dan adat istiadat suatu daerah tertentu. Didalam lagu tersebut terkandung suatu makna, pesan untuk masyarakat serta suasana/keadaan masyarakat setempat, dan bahasa yang digunakan adalah bahasa daerah setempat. Pada penulisan ini, penulis mengambil lagu Tokecang yang berasal dari Jawa Barat dan memiliki nada yang menyenangkan untuk didengar oleh semua kalangan baik dari anak-anak, remaja, 
maupun dewasa. Ali (2010) menjelaskan salah satu ciri khas lagu daerah adalah jarang diketahui penggarangnya, untuk lagu Tokecang belum diketahui siapa yang mengarang lagu tersebut. Berikut lirik/syair lagu Tokecang dan arti dalam Bahasa Indonesia:

Tabel 1. Lirik/Syair beserta Arti dari Bahasa Indonesia

\begin{tabular}{|c|c|}
\hline $\begin{array}{c}\text { Lirik/Syair lagu } \\
\text { Tokecang }\end{array}$ & $\begin{array}{c}\text { Arti } \\
\text { Lirik/Syair } \\
\text { Lagu } \\
\text { Tokecang }\end{array}$ \\
\hline Tokecang & Tokecang, \\
\hline $\begin{array}{l}\text { tokecang bala } \\
\text { gendir tosblong } \\
\text { Angeun kacang } \\
\text { sapependil } \\
\text { kosong }\end{array}$ & $\begin{array}{l}\text { tokecang bala } \\
\text { gendir bolong } \\
\text { sayur kacang, } \\
\text { sayur kacang } \\
\text { satu periuk } \\
\text { kosong }\end{array}$ \\
\hline $\begin{array}{l}\text { Aya listrik di } \\
\text { masigit meuni } \\
\text { caang katingalna }\end{array}$ & $\begin{array}{l}\text { Ada listrik di } \\
\text { mesjid sampai } \\
\text { silau }\end{array}$ \\
\hline $\begin{array}{lr}\text { Aya } & \text { istri } \\
\text { jangkung } & \text { alit }\end{array}$ & $\begin{array}{l}\text { kelihatannya } \\
\text { ada istri tinggi }\end{array}$ \\
\hline $\begin{array}{l}\text { karangan dina } \\
\text { pipina }\end{array}$ & $\begin{array}{l}\text { kurus ada tahi } \\
\text { lalat di pipinya }\end{array}$ \\
\hline Tokecang & $\begin{array}{l}\text { Tokecang, } \\
\text { tokecang bala }\end{array}$ \\
\hline $\begin{array}{l}\text { tokecang bala } \\
\text { gendir tosblong }\end{array}$ & $\begin{array}{l}\text { gendir bolong } \\
\text { sayur kacang, }\end{array}$ \\
\hline Angeun kacang & sayur kacang \\
\hline $\begin{array}{l}\text { angeun kacang } \\
\text { sapependil } \\
\text { kosong }\end{array}$ & $\begin{array}{ll}\text { satu periuk } \\
\text { kosong }\end{array}$ \\
\hline
\end{tabular}

Pada arti tersebut lagu Tokecang menceritakan tentang seseorang yang senang makan secara berlebihan atau makan sampai melampaui batas. Tembang Tokecang sendiri merupakan sebuah singkatan dari Tokek Makan Kacang yang terkandung di dalamnya mengingatkan bahwa makan banyak atau makan berlebihan tidak baik sebab, hal ini melambangkan kerakusan atau keserakahan sehingga tidak memiliki kepedulian terhadap orang lain dan hanya memikirkan tentang dirinya sendiri. Pada dasarnya manusia merupakan mahluk sosial yang saling membutuhkan antara yang satu dengan yang lainnya dan seharusnya bisa saling berbagi dan tolong menolong. Tambahan informasi yang diperoleh penulis dengan mewawancarai guru Bahasa Sunda SMK Sukaraja Garut, menjelaskan bahwa lagu Tokecang dinyanyikan anak anak kecil untuk mengisi waktu dan membuang rasa bosan karena teman-temannya belum datang. Lagu ini menggunakan tempo yang cepat disertai isi pada bait pertama menjelaskan tokek makan kacang kemudian makan kembali sayur kacang sampai kosong atau habis. Selanjutnya dilirik/syair kedua sebuah pantun jenaka menyebutkan ada listrik/cahaya di mesjid terang sekali, kemudian ada wanita cantik yang memiliki tahi lalat di pipinya. Lirik yang sederhana dan mudah dihapal serta dialek mudah diucapkan membuat lagu ini cocok dinyanyikan oleh anak-anak. Dengan lagulagu daerah yang mencerminkan sikapsikap positif akan memudahkan untuk diserap dalam pengembangan karakter yang baik. Sesuai Undang-Undang Republik Indonesia No. 20 tahun 2003 tentang Sistem Pendidikan Nasional menyebutkan bahwa tujuan pendidikan nasional adalah mengembangkan kemampuan dan membentuk watak serta peradaban bangsa yang bermartabat dalam rangka mencerdaskan kehidupan bangsa. 


\section{7 | JURNAL ILMU BUDAY A}

Volume 8, Nomor 1, 2020

E-ISSN: 2621-5101

Oleh karena itu peran sekolah dan keluarga juga penting dalam menerapkan lagu-lagu daerah dalam membentuk karakterkarakter yang positif.

Megawangi (2010) menyebutkan sembilan karakter yang penting untuk ditanamkan dalam pembentukan karakter anak. Berbagai karakter tersebut sejalan dengan nilai-nilai kearifan lokal yang mengandung nilai-nilai luhur universal. Pembentukan karakter anak pada Lagu Tokecang mengajarkan bahwa kita sebagai makhluk sosial harus memiliki sikap kasih sayang dan kepedulian sosial. Kasih sayang adalah reaksi emosional terhadap seseorang, binatang, atau benda (Nurhayati, 2011). Hal itu menunjukkan perhatian yang hangat, dan mungkin terwujud dalam bentuk fisik atau kata-kata (verbal). Sedangkan karakter kepedulian sosial menurut Warsah (2015) dapat ditunjukan dengan memperlakukan sesama teman atau orang-orang disekeliling dengan bertindak seperti mau berbagi, membantu dan bekerja sama. Jika perbuatan baik yang diberikan maka akan mendapat balasan yang baik, tetapi jika perbuatan yang jahat maka akan mendapat balasan yang jahat pula.

\section{KESIMPULAN}

Kesimpulan pada penulisan ini bahwa lagu-lagu daerah penting berikan untuk anak-anak. Karena lagu-lagu daerah mengandung nilai-nilai kehidupan, unsurunsur kebersamaan sosial, serta keserasian dengan lingkungan hidup sekitar. Termasuk pada lirik atau syair tembang lagu Tokecang yang iramanya menyenangkan dan sederhana. Lagu tersebut jika ditelusuri dapat membentuk karakter anak-anak dengan menumbuhkan sikap kasih sayang dan kepedulian antar manusia.

\section{DAFTAR PUSTAKA}

Ali, Matius. 2010. Seni Musik 2 untuk SMP dan MTS kelas VIII. Jakarta : Esis

Banoe, Pono. 2011. Kamus Musik. Yogyakarta : Kanisius

Malatu. 2014. Seni Musik 1 untuk Kelas VII SMP dan MTs. Surakarta : PT. Tiga Serangkai Pustaka Mandiri.

Megawangi, Ratna. 2010. Membangun Karakter Anak melalui Brain-based Parenty (Pola Asuh) Ramah Ota.

Kartini, Yuyun. 2014. Tembang Dolanan Anak-anak berbahasa Jawa Sumber Pembentukan Watak dan Budi Pekerti. Sidoarjo: Balai Bahasa Provinsi Jawa Timur.

Nurhidayati, Titin. 2011. Pendekatan Kasih Sayang: Solusi Pengembangan Karakter Terpuji Dan Akhlak Mulia Dalam

Diri Anak Didik. 2011. Jurnal Falasifa. Vol. 2 (2).

Setyobudi, dkk. 2007. Seni Budaya untuk SMP Kelas VIII. Jakarta : Erlangga.

Idi Warsah. (2015). Implementasi Nilai Kepedulian Sosial dalam Pendidikan Karakter Melalui Interaksi Sosial. budayajawa.id/makna-lagu-jawabarat-tokecang Diyoswirinata. Budaya indonesia.org/Tokecang-2. Tanggal terbit 10 Februari 2015

Hari, Ananto. www.intipesan.com/sp 22394/. Juni 14, 2016

Pambudi, Joko. www.pikiranrakyat.com/bandungraya/2016/05/28/lagu-Daerahpenting-untuk-pembentukankarakter-anak-370229. Lagu Daerah Penting untuk Pembentukan Karakter Anak. Tanggal terbit 28 Mei, 2016.

Aceng, guru Bahasa Sunda SMK Sukaraja Garut. 2017. 